\title{
COMPUTATION OF THERMODYNAMIC PARAMETERS OF BINARY METAL SYSTEMS WITH LIMITED SOLUBILITY OF COMPONENTS IN THE SOLID $\alpha$-PHASE
}

\author{
A.P. Shcherban, O.A. Datsenko \\ National Science Center "Kharkov Institute of Physics and Technology”, Kharkiv, Ukraine \\ E-mail: shcherban@kipt.kharkov.ua
}

In the region of the primary solid $\alpha$-phase for systems with limited solubility thermodynamic quantities such as the partial enthalpy of dissolution $\Delta \bar{H}_{B}^{\alpha}$, the activity coefficients $\gamma_{B}^{\alpha}$ and the activities $a_{B}^{\alpha}$ in binary metal systems were calculated. The above mentioned indicated values were determined from the relations that connect these parameters with the equilibrium distribution coefficient $\mathrm{k}_{0 \mathrm{~B}}$ and known thermodynamic quantities, such as the enthalpy variation $\Delta H_{\mathrm{mB}}$ and entropy variation $\Delta S_{\mathrm{mB}}$ during melting of component $\mathrm{B}$. The calculation of equilibrium distribution coefficients using data from experimentally constructed solidus and liquidus lines of state diagrams was performed. The values and temperature dependences of the dissolution enthalpy for such systems as $\mathrm{Ag}-\mathrm{Mg}, \mathrm{Nb}-\mathrm{Ge}, \mathrm{Mg}-\mathrm{Al}, \mathrm{Mg}-\mathrm{Ag}, \mathrm{Al}-\mathrm{Mg}, \mathrm{Ni}-\mathrm{Ga}$, as well as the values and dependences of the activity coefficients $\gamma_{B}^{\alpha}$ and activities $a_{B}^{\alpha}$ of the second component on these systems were determined.

PACS: $65.40 . \mathrm{Gr}$

\section{INTRODUCTION}

The formation of solid solutions occupies an important place in the thermodynamics of a solid state. Both in nature and in technology, one constantly has to deal with solutions, and not with pure components. Pure substances are only a limiting state that is never really achieved. In physicochemical analysis, an important aspect is the establishment of a relationship between the composition and properties of compound systems. For a quantitative calculation of the formation of solid solutions and alloys, an approach of interest is the one in which the equilibrium temperatures between the liquid and solid phases, as well as the temperatures of phase equilibria in the solid state, are chosen as the main property.

In the formation of solid solutions one of the main thermodynamic parameters is the partial enthalpy of dissolution of the element $\Delta \bar{H}_{B}^{\alpha}$ dissolved in the $\alpha$ phase of the primary solid solution. Other important thermodynamic quantities are the activity coefficients $\gamma_{B}^{\alpha}$ and the activity $a_{B}^{\alpha}$ of the soluble component in the solid state. Reference data on the value of thermodynamic values of dissolution are very limited, and for most metal systems they are completely absent. It is of practical interest to determine the value of these thermodynamic quantities for systems with limited solubility of the components in the base.

One of the necessary parameters for calculating the thermodynamic quantities during the formation of solid solutions of binary metallic systems is the equilibrium distribution coefficient $\mathrm{k}_{0 \mathrm{~B}}$. The value of $\mathrm{k}_{0 \mathrm{~B}}$ was determined from the phase equilibria of the binary state diagrams (SD) as the ratio of the concentration of the second component in the solid and liquid phases $\mathrm{x}_{\mathrm{SB}} / \mathrm{x}_{\mathrm{LB}}$. The main types of phase equilibria are presented in [1].

In this work the calculation method for determining the values of the above parameters in binary metal systems with limited solubility of the second component in the base was studied. The calculations for binary metal systems such as $\mathrm{Ag}-\mathrm{Mg}, \mathrm{Nb}-\mathrm{Ge}, \mathrm{Mg}-\mathrm{Al}, \mathrm{Mg}-\mathrm{Ag}$, $\mathrm{Al}-\mathrm{Mg}, \mathrm{Ni}-\mathrm{Ga}$ were performed.

\section{FORMULATION OF THE PROBLEM}

The method for determining the thermodynamic quantities: $\Delta \bar{H}_{B}^{\alpha}, \quad \gamma_{B}^{\alpha}$ and $a_{B}^{\alpha}$ of the dissolved element for binary metal systems with low solubility of the second component in the solid $\alpha$-phase was developed by the authors of this work [2]. The values and temperature dependences of the dissolution enthalpy $\Delta \bar{H}_{B}^{\alpha}$ of the sparingly soluble component, as well as the activity $a_{B}^{\alpha}$ and activity coefficients $\gamma_{B}^{\alpha}$ of the second component in the saturated $\alpha$-phase for such systems as $\mathrm{Cd}-\mathrm{Na}, \mathrm{Cd}-\mathrm{Tl}, \mathrm{Te}-\mathrm{Ga}, \mathrm{Te}-\mathrm{As}, \mathrm{Te}-\mathrm{Cu}$ were determined by the proposed method.

The determination of thermodynamic quantities for systems with limited solubility is based on the method described in [2]. The difference from systems with low solubility takes place in the determination of the equilibrium distribution coefficients $\mathrm{k}_{0 \mathrm{~B}}$ necessary for calculations depending on the dissolution temperature. For systems with low solubility, the procedure for determining $\mathrm{k}_{0 \mathrm{~B}}$ requires additional calculations [3-5]. Since experimentally constructed lines of solidus and liquidus of SD are known for systems with limited solubility, their analysis allows one to directly determine the values $k_{O B}$.

The aim of this work is to determine the values of such thermodynamic parameters as the partial dissolution enthalpy $\Delta \bar{H}_{B}^{\alpha}$, activity coefficient $\gamma_{B}^{\alpha}$, and activity $a_{B}^{\alpha}$ of the second component in binary metal systems with limited solubility of the components in a solid state. 


\section{CALCULATION METHOD}

The distribution coefficients $\mathrm{k}_{0 \mathrm{~B}}$ were determined from the pairs of temperatures and concentrations $\mathrm{T}_{\mathrm{S}(\mathrm{i})}$, $\mathrm{x}_{\mathrm{SB}(\mathrm{i})}$ and $\mathrm{T}_{\mathrm{L}(\mathrm{j})}, \mathrm{x}_{\mathrm{LB}(\mathrm{j})}$ taken from the corresponding state diagrams in the range from the melting temperature $T_{M A}$ of the main component to the maximum solution temperature close to the eutectic temperature $\mathrm{T}_{\max } \sim \mathrm{T}_{\mathrm{EA}}$. Using the pairs of temperature values $\left({ }^{\circ} \mathrm{C}\right)$ and the corresponding concentrations (at.\%) of the maximum solubility of the second component in the solid and liquid phase taken from the state diagrams, the distribution coefficient $\mathrm{k}_{0 \mathrm{~B}}$ was determined (see Table):

$$
k_{0 B}=x_{S B} / x_{L B} .
$$

It should be noted a slight increase in the distribution coefficient $\mathrm{k}_{0 \mathrm{~B}}$ for all systems in the selected range of temperatures and concentrations of the second component. The maximum variation $\mathrm{k}_{0}$, about 2.1 times, was observed for $\mathrm{Mg}-\mathrm{Ag}$ and $\mathrm{Nb}-\mathrm{Ge}$ systems.

The values of $\mathrm{k}_{0 \mathrm{~B}}$ obtained above were used to determine the partial dissolution enthalpy $\Delta \bar{H}_{B}^{\alpha}$ from the relation obtained in [6] and transformed to the form (2)

$$
\Delta \overline{\mathrm{H}}_{\mathrm{B}}^{\alpha}=-R T \ln k_{0 B}+\Delta H_{\mathrm{mB}}-T \Delta S_{\mathrm{mB}},
$$

where $\Delta \bar{H}_{B}^{\alpha}$ is the partial enthalpy of dissolution of component $\mathrm{B}$ in the $\alpha$-phase at temperature $\mathrm{T} ; \mathrm{k}_{0 \mathrm{~B}}$ is the equilibrium distribution coefficient; $\Delta H_{\mathrm{mB}}$ melting enthalpy of component $\mathrm{B} ; \mathrm{R}$ is the universal gas constant; $\Delta S_{\mathrm{mB}}$ is the melting entropy of component $\mathrm{B}$.

The conclusion of the desired expression (2) is made under the assumption that the primary solid $\alpha$-phase behaves as a regular solution, and the liquid phase, which is in equilibrium with the solid phase above the eutectic temperature, behaves as an ideal solution.

When the value $\Delta \bar{H}_{B}^{\alpha}$ is known, it is possible to determine the activity coefficient $\gamma_{B}^{\alpha}$ from expression (3), which is included in the expression of the chemical potential of the component for a real solution, characterizing the deviation of the system from ideal behavior [6]:

$$
R T \ln \gamma_{B}^{\alpha}=\Delta \bar{H}_{B}^{\alpha},
$$

where $\gamma_{B}^{\alpha}$ the activity coefficient of component B in the saturated $\alpha$-phase at temperature T; $\Delta \bar{H}_{B}^{\alpha}, \mathrm{R}$ are the same quantities as in (2).
From the thus determined values of the activity coefficients $\gamma_{B}^{\alpha}$, the activity $a_{B}^{\alpha}$ of component B in the $\alpha$-phase was also calculated depending on the saturation concentration, using the following expression.

$$
a_{B}^{\alpha}=\gamma_{B}^{\alpha} x_{\mathrm{B}}^{\alpha}
$$

where $a_{B}^{\alpha}$ is the activity of component $\mathrm{B}$ in the saturated $\alpha$-phase, $\% ; \gamma_{B}^{\alpha}$ is activity coefficient; $x_{B}^{\alpha}$ is component B concentration on the solidus line, at. $\%$.

\section{RESULTS AND DISCUSSION}

For the studied systems Ag-Mg, Nb-Ge, Ni-Ga, Mg$\mathrm{Ag}, \mathrm{Al}-\mathrm{Mg}, \mathrm{Mg}-\mathrm{Al}$, the temperature dependences of the values $\Delta \bar{H}_{B}^{\alpha}$, calculated by formula (2) were shown in Fig. 1

Reference data of the enthalpy $\Delta H_{\mathrm{mB}}$ and melting entropy $\Delta S_{\mathrm{mB}}$ of the dissolved component for calculations were taken from [7].

An analysis of the results obtained on the dissolution enthalpy shows that in the systems under study a change in the partial enthalpies with a change in the dissolution temperature was observed. With decreasing temperature of the solution, a decrease in the partial enthalpies of dissolution of the second component was observed. From the general regularity of the positive values of the partial dissolution enthalpies for the studied systems, the distinctive feature was shown by the $\mathrm{Nb}-\mathrm{Ge}$ and $\mathrm{Ni}-\mathrm{Ga}$ systems, which were characterized by a negative value $\Delta \bar{H}_{B}^{\alpha}$. A negative value $\Delta \bar{H}_{B}^{\alpha}$ indicates the exothermic dissolution of germanium in niobium and gallium in nickel, in contrast to other systems in which the dissolution of the second component occurs with heat absorption.

Fig. 2 shows the graphical dependences of activity coefficients $\gamma_{B}^{\alpha}$ as a function of the reciprocal temperature for the systems studied. The obtained data of the dependence of activity coefficients $\gamma_{B}^{\alpha}$ on temperature show that in the systems under study, a decrease in the value of activity coefficients is observed with a decrease in the dissolution temperature.

An insignificant (1.2..2.1 times) temperature dependence of the activity coefficients was observed for the systems under study in a given range of temperatures and concentrations of the second component and a slight concavity of the dependence curves $\gamma_{B}^{\alpha}=\mathrm{f}(1 / \mathrm{T})$. 

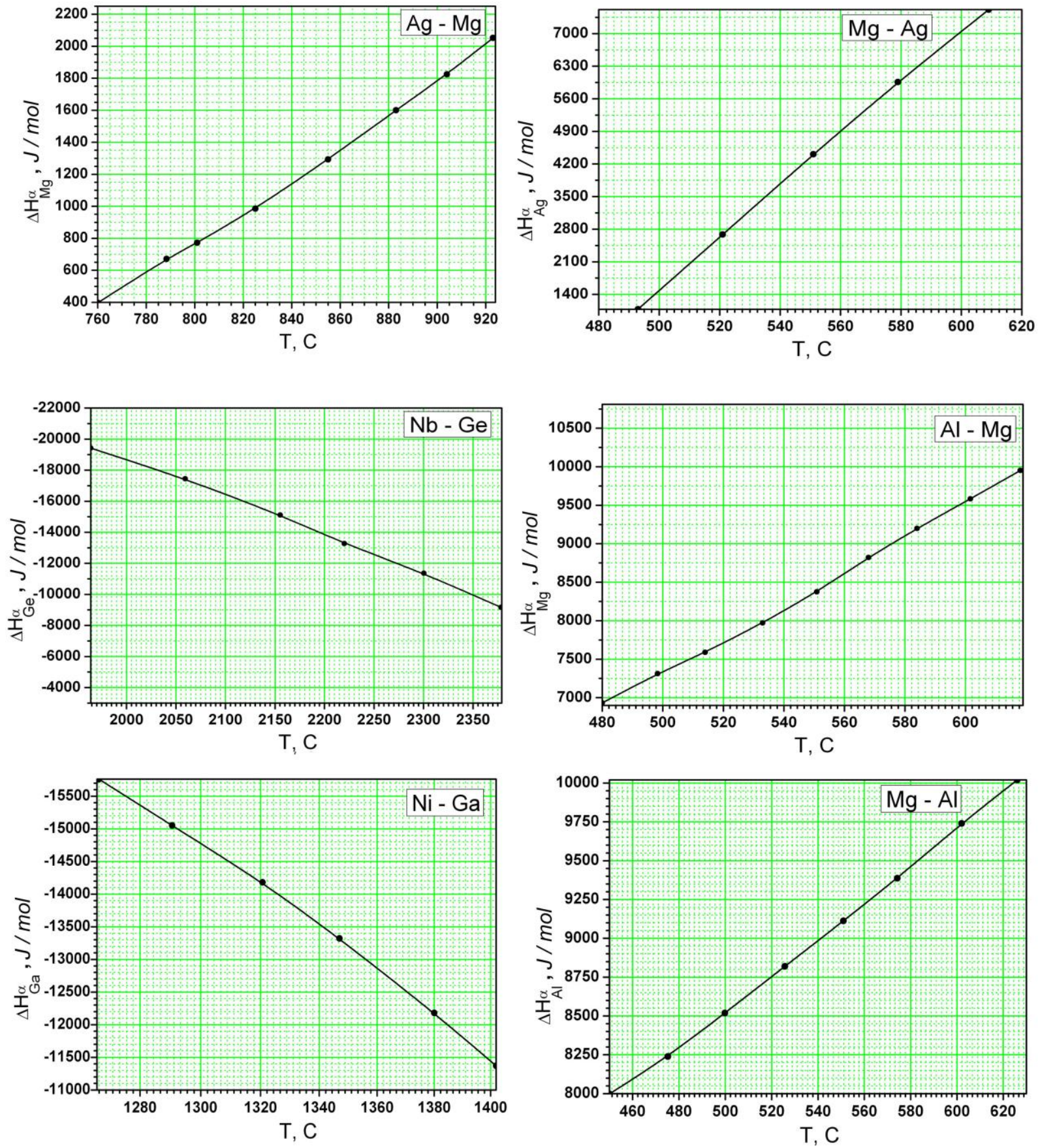

Fig. 1. The temperature dependence of the dissolution enthalpy of the second component in the base for systems: $A g-M g, N b-G e, N i-G a, M g-A g, A l-M g, M g-A l$

If the activity coefficients of the second component in the solid phase is known, it is possible to determine the activity $a_{B}^{\alpha}$ of component B itself, depending on the concentration of maximum solubility. Activity was determined using expression (4).

The calculated values of the obtained thermodynamic quantities of the second component in the systems under study for three values of temperatures and concentrations were showed in the Table.
The temperatures and the corresponding concentrations of the second component are selected for three arbitrary values on the SD.

An analysis of the values for the activities of the second component shows that with a decrease in the temperature of the solution there is an increase in the activities of the second component in the process of its dissolution for all studied systems.

The $\mathrm{Mg}-\mathrm{Ag}$ system was characterized by a minimum change in activity of 1.9 times, and the Nb-Ge system by a maximum of 3.7 times. 

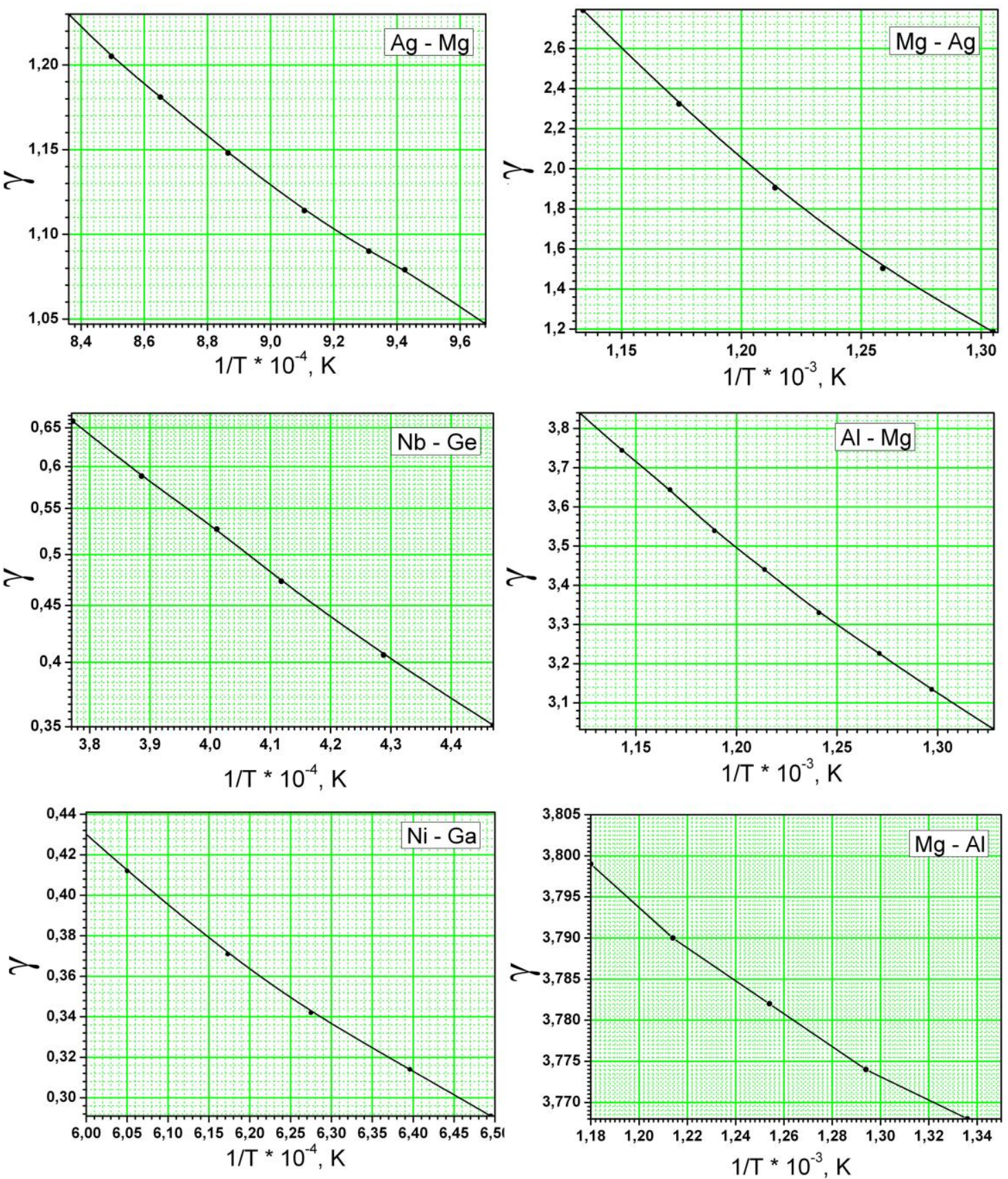

Fig. 2. The values of the activity coefficient of the second component in the solid $\alpha$-phase depending on the inverse temperature for systems $\mathrm{Ag}-\mathrm{Mg}, \mathrm{Nb}-\mathrm{Ge}, \mathrm{Mg}-\mathrm{Al}, \mathrm{Mg}-\mathrm{Ag}, \mathrm{Al}-\mathrm{Mg}, \mathrm{Ni}-\mathrm{Ga}$

The values of thermodynamic quantities of the studied systems for the selected temperatures and concentrations

\begin{tabular}{|c|c|c|c|c|c|c|}
\hline System & $T,{ }^{\circ} \mathrm{C}$ & $x_{\mathrm{s}}$, at. $\%$ & $k_{0}$ & $H, \mathrm{~J} / \mathrm{mol}$ & $\gamma$ & Activity, $\%$ \\
\hline \multirow{4}{*}{ Ag-Mg } & 904 & 7.6 & 0.65 & 1825 & 1.21 & 9.13 \\
\cline { 2 - 7 } & 825 & 18.1 & 0.75 & 985 & 1.11 & 20.17 \\
\cline { 2 - 7 } & 788 & 23.5 & 0.80 & 671 & 1.08 & 25.22 \\
\hline \multirow{3}{*}{ Nb-Ge } & 2341 & 1.3 & 0.20 & -10190 & 0,63 & 0,79 \\
\cline { 2 - 7 } & 2220.1 & 3.1 & 0.26 & -13270 & 0,53 & 1,63 \\
\cline { 2 - 7 } & 2011 & 7.6 & 0.41 & -18190 & 0,38 & 2,91 \\
\hline \multirow{3}{*}{$\mathrm{Mg}-\mathrm{Al}$} & 602 & 2.7 & 0.29 & 9739 & 3.82 & 10.32 \\
\cline { 2 - 7 } & 525.7 & 6.7 & 0.33 & 8852 & 3.80 & 25.35 \\
\cline { 2 - 7 } & 475.2 & 9.8 & 0.37 & 8238 & 3.77 & 36.89 \\
\hline \multirow{3}{*}{$\mathrm{Mg}-\mathrm{Ag}$} & 579 & 0.8 & 0.09 & 5959 & 2.32 & 1.86 \\
\cline { 2 - 7 } & 521 & 2 & 0.15 & 2684 & 1.50 & 3.01 \\
\cline { 2 - 7 } & 493 & 3 & 0.19 & 1082 & 1.19 & 3.56 \\
\hline
\end{tabular}




\begin{tabular}{|c|c|c|c|c|c|c|}
\hline \multirow{3}{*}{ Al-Mg } & 601.6 & 3.3 & 0.29 & 9583 & 3.74 & 12.35 \\
\cline { 2 - 7 } & 550.9 & 7.2 & 0.34 & 8375 & 3.40 & 24.50 \\
\cline { 2 - 7 } & 498.3 & 12 & 0.40 & 7312 & 3.13 & 37.60 \\
\hline \multirow{3}{*}{ Ni-Ga } & 1402 & 3.6 & 0.37 & -11370 & 0.44 & 1.57 \\
\cline { 2 - 7 } & 1347 & 7.5 & 0.44 & -13320 & 0.37 & 2.79 \\
\cline { 2 - 7 } & 1290.6 & 12.4 & 0.53 & -15050 & 0.31 & 3.89 \\
\hline
\end{tabular}

\section{CONCLUSIONS}

The values and temperature dependences of the dissolution enthalpy $\Delta \bar{H}_{B}^{\alpha}$ of the sparingly soluble second component were determined for the Ag- Mg, NbGe, Mg-Al, Mg-Ag, Al-Mg, and Ni-Ga systems.

$\mathrm{The} \mathrm{Nb}-\mathrm{Ge}$ and $\mathrm{Ni}-\mathrm{Ga}$ systems were characterized by a negative value $\Delta \bar{H}_{B}^{\alpha}$, which indicated the exothermic process of dissolution of germanium in niobium and gallium in nickel. In $\mathrm{Ag}-\mathrm{Mg}, \mathrm{Mg}-\mathrm{Al}, \mathrm{Mg}$ $\mathrm{Ag}, \mathrm{Al}-\mathrm{Mg}$ systems, the dissolution of the second component occurs with heat absorption.

The obtained data of the dependence of activity coefficients $\gamma_{B}^{\alpha}$ on temperatures show that in the studied systems with a decrease in the dissolution temperature there is a not significant decrease of 1.2..2.1 times the value of the activity coefficients for the studied systems.

For the systems under study, the activity $a_{B}^{\alpha}$ of the components in the saturated solid phase was determined depending on temperature and concentration. An increase in dissolution activities of the second component is observed with a decrease in temperature in a given range of temperatures and concentrations.

\section{REFERENCES}

1. Edited by N.P. Lyakishev. Phase diagrams of binary metal system. M.: "Mashinostroyeniye", 1996, v. 1, 992 p.; M.: "Mashinostroyenoye", 1997, v. 2, 1024 p. M.: "Mashinostroyeniye", 2001, v. 3, 872 p. (in Russian).

2. A.P. Shcherban, O.A. Datsenko. Determination of the thermodynamic quantities of binary metal systems with low solubility of components in the solid $\alpha$-phase // East Eur. J. Phys. 2018, v. 5, N 3, p. 75-81.

3. A.P. Shcherban. The limiting distribution coefficients of low-soluble impurities in metals // Journal of V.N. Karazin Kharkiv National University. Series Nuclei, particles, fields. 2011, N 946, issue 1(49), p. 75-80.

4. A.P. Scherban', O.A. Datsenko. Analysis of phase diagrams of binary metal systems in the field at low concentration of components // Journal of V.N. Karazin Kharkiv National University. Series "Nuclei, particles, fields". 2013, N 1069, issue 4(60), p. 95-99.

5. A.P. Shcherban, O.A. Datsenko, G.P. Kovtun. Construction of solidus lines of binary metal systems having a low solubility of components in the solid phase // Open Journal of Metal. 2014, v. 4, p. 65-71.

6. R.A. Svellin. Solid phase thermodynamics. M.: "Metallurgiya", 1968, 316 p.

7. L. Kuchař, B. Wozniaková, J. Drápala. Segregation behaviour during the zone melting of refractory metals // Journal of Crystal Growth., 1981, v. 52 , p. $359-366$

Article received 04.10.2019

\title{
РАСЧЕТ ТЕРМОДИНАМИЧЕСКИХ ПАРАМЕТРОВ БИНАРНЫХ МЕТАЛЛИЧЕСКИХ СИСТЕМ С ОГРАНИЧЕННОЙ РАСТВОРИМОСТЬЮ КОМПОНЕНТОВ В ТВЕРДОЙ $\alpha-$ ФАЗЕ
}

\author{
А.П. Щербань, О.А. Даценко
}

В области первичной твердой $\alpha$-фазы для систем с ограниченной растворимостью выполнен расчет значений таких термодинамических величин, как парциальная энтальпия растворения $\Delta \bar{H}_{B}^{\alpha}$, коэффициенты активности $\gamma_{B}^{\alpha}$ и активность $a_{B}^{\alpha}$ компонентов в двойных металлических системах. Выше указанные величины определяли из соотношений, которые связывают эти параметры с равновесным коэффициентом распределения $k_{0 B}$ и известными термодинамическими величинами, такими как изменения энтальпии $\Delta H_{\text {плB }}$ и энтропии $\Delta S_{\text {плB }}$ при плавлении компонента $B$. Расчет равновесных коэффициентов распределения выполняли с использованием данных экспериментально построенных линий солидуса и ликвидуса диаграмм состояния. Определены значения и зависимости от температуры энтальпии растворения для таких систем, как $\mathrm{Ag}-\mathrm{Mg}, \mathrm{Nb}-\mathrm{Ge}, \mathrm{Mg}-\mathrm{Al}, \mathrm{Mg}-\mathrm{Ag}, \mathrm{Al}-\mathrm{Mg}, \mathrm{Ni}-\mathrm{Ga}$, а также значения и зависимости от температуры растворения коэффициентов активности $\gamma_{B}^{\alpha}$ и активность $a_{B}^{\alpha}$ второго компонента в этих системах. 


\section{РОЗРАХУНОК ТЕРМОДИНАМІЧНИХ ПАРАМЕТРІВ БІНАРНИХ МЕТАЛЕВИХ СИСТЕМ 3 ОБМЕЖЕНОЮ РОЗЧИННІСТЮ КОМПОНЕНТІВ У ТВЕРДІЙ $\alpha$-ФАЗІ}

\section{О.П. Щербань, О.А. Даценко}

В області первинної твердої $\alpha$-фази для систем з обмеженою розчинністю зроблено розрахунок значень таких термодинамічних величин, як парціальна ентальпія розчинення $\Delta \bar{H}_{B}^{\alpha}$, коефіцієнти активності $\gamma_{B}^{\alpha} \mathrm{i}$ активність $a_{B}^{\alpha}$ компонентів у бінарних металевих системах. Вище зазначені величини визначали із співвідношень, які пов'язують ці параметри 3 рівноважним коефіцієнтом розподілу $k_{0 B}$ i відомими термодинамічними величинами, такими як зміна ентальпії $\Delta H_{\text {плв }}$ і зміна ентропії $\Delta S_{\text {плв }}$ при плавленні компонента $B$. Розрахунок рівноважних коефіцієнтів розподілу виконували 3 використанням даних експериментально побудованих ліній солідусу і ліквідусу діаграм стану. Визначено значення і температурні залежності ентальпії розчинення для таких систем, як $\mathrm{Ag}-\mathrm{Mg}, \mathrm{Nb}-\mathrm{Ge}, \mathrm{Mg}-\mathrm{Al}, \mathrm{Mg}-\mathrm{Ag}, \mathrm{Al}-\mathrm{Mg}, \mathrm{Ni}-\mathrm{Ga}$, а

також значення і залежності від температури розчинення коефіцієнтів активності $\gamma_{B}^{\alpha}$ та активність $a_{B}^{\alpha}$ другого компонента в цих системах. 